\title{
The ongoing energy transition: Lessons from a socio-technical, multi-level analysis of the Dutch electricity system (1960-2004)
}

\author{
Geert Verbong*, Frank Geels \\ Eindhoven University of Technology, IPO Building, Room 2.22, P.O. Box 513, 5600 MB Eindhoven, The Netherlands
}

Available online 31 March 2006

\begin{abstract}
Energy transitions to sustainability receive much interest in politics and science. Using a socio-technical and multi-level theory on transitions, this article draws important lessons from a long-term analysis of the Dutch electricity system. The article analyses technical developments, changes in rules and visions, and social networks that support and oppose renewable options. The article is multi-level because it looks at novel renewable energy technologies and structural trends in the existing electricity regime. The analysis shows that an energy transition, with roots in the 1960s and 1970s, is already occurring, but driven mainly by liberalisation and Europeanisation. Environmental aspects have become part of this ongoing transition, but do not form its main driver. Many barriers exist for a sustainability transition, but there are also some opportunities. A long-term analysis of renewable niche-innovation trajectories (wind, biomass, PV) provides lessons about socio-technical dynamics, problems and windows of opportunity.
\end{abstract}

(C) 2006 Elsevier Ltd. All rights reserved.

Keywords: Energy transition; Long-term socio-technical analysis; Dutch electricity system

\section{Introduction}

The energy sector faces serious problems, e.g. oil dependency, reliability and environmental problems. Large jumps in environmental efficiency may be possible with transitions to a new energy system (Weaver et al., 2000). Hence, NGOs and policy makers show increasing interest in transitions (Raskin et al., 2002). The Dutch government gave transitions a central place in its fourth National Environmental Policy Plan (VROM, 2001) as did the Ministry of Economic Affairs (2005) in its recent Energy Report. Academics also show increasing interest in the underlying dynamics of transitions (Elzen et al., 2004; Geels, 2002, 2005) or governance aspects (Rotmans et al., 2001). Although there is much talk in the Netherlands about energy transitions, implementation of renewable energy is low compared to other European countries (Fig. 1).

The low Dutch share of renewable energy is not for lack of efforts. Since the 1970s there have been many activities to develop and implement renewable energy options. In a

\footnotetext{
*Corresponding author. Tel.: + 31402472698 .

E-mail address: g.p.j.verbong@tm.tue.nl (G. Verbong).
}

recent Energy Policy article, Van der Vleuten and Raven (2006) demonstrated the usefulness of a long-term analysis, showing that long-term dynamics of Danish energy regimes at the meso-level were just as important as specific energy policies at the micro-level to understand the relative success of distributed generation. We will follow their example and explain the low Dutch share of renewable energy from a long-term regime analysis. The article focuses on the electricity sector, a domain for which Van Rooijen and Van Wees (2006) analysed renewable electricity policies in the last 15 years. Their description of policy changes is very good, but their analysis has some white spots. First, they implicitly link the relatively low share of renewable electricity to policy. But although policy makers are important, other actors are also involved in renewable options (e.g. firms, utilities, special-interest groups, consumers). A proper explanation should also include perceptions, strategies and actions of these groups. This is in line with the shift in policy studies from 'government' to 'governance' (e.g. Kooiman, 1993). Governance means that directionality and coordination in a particular domain has an emergent character, arising from interactions between multiple groups. Public authorities may try to influence this emergent directionality, but cannot steer it at will. The 


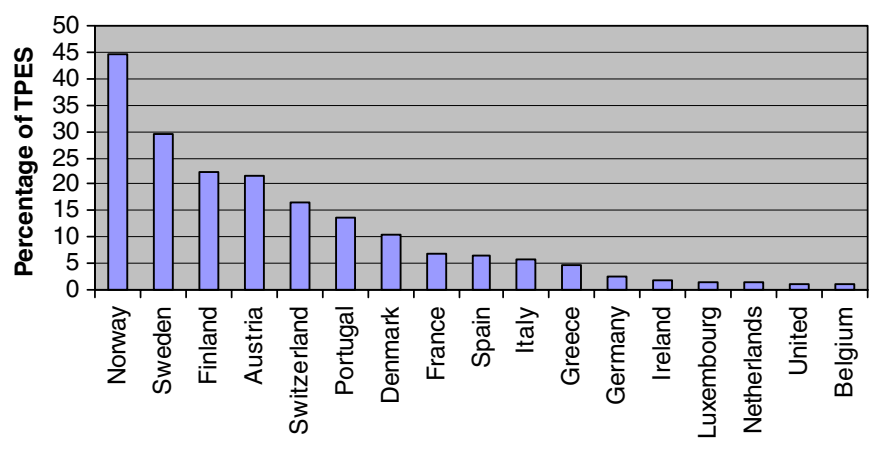

Fig. 1. Share of total renewable energy sources in primary energy supply in several European countries in 2001 (IEA, 2003).

second white spot is that the article neglects broader energy regimes in which renewable policies and options are embedded. On both points, this article suggests improvements. First, it makes a long-term multi-actor analysis of the electricity regime. Second, it analyses innovation journeys of renewable electricity options and their interactions with regime developments.

The literature on innovation systems is only partially useful for our aims. The sectoral systems of innovation approach (Malerba, 2002) focuses on the functioning of systems, making static, comparative analysis of the innovative performance of sectors. The topic of change is explicitly addressed in technology-specific innovation systems (Jacobsson and Bergek, 2004). This literature focuses on the actors and learning processes in new technologies, but pays less attention to existing technologies and regimes. Given our interest in transitions, we use the multi-level perspective (MLP), which looks at interactions between niche-innovations and existing regimes, situated in a broader environment. The MLP stems from evolutionary economics and sociology of technology (Rip and Kemp, 1998; Geels, 2002).

The socio-technical regime forms the meso-level in the MLP. It consists of three interlinked dimensions (Geels, 2005): (a) network of actors and social groups; in the electricity regime important actors are utilities, the Ministry of Economic Affairs, large industrial users, and households; (b) formal, normative and cognitive rules that guide the activities of actors; examples of formal rules are regulations, standards, laws; examples of cognitive rules are belief systems, problem agenda's, guiding principles, search heuristics; examples of normative rules are role relationships, behavioural norms, (c) material and technical elements; in the case of electricity, these include resources, grid, generation plants, etc. Existing sociotechnical regimes are characterised by path dependence and lock-in, resulting from stabilising mechanisms on the three dimensions (Unruh, 2000; Walker, 2000): (a) incumbent actors have vested interests; social networks represent 'organizational capital', (b) regulations and standards may stabilise regimes; cognitive routines may blind actors to developments outside their focus; (c) existing machines and

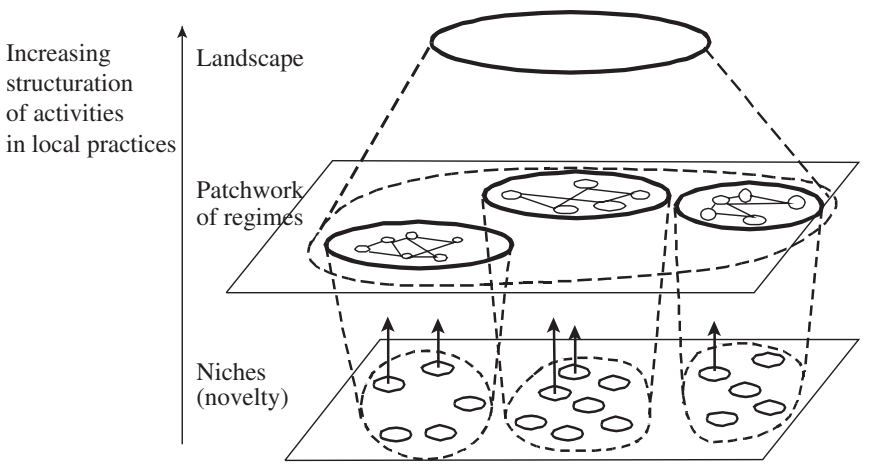

Fig. 2. Multiple levels as a nested hierarchy (Geels, 2002, p. 1261).

infrastructures stabilise through sunk investments and technical complementarities between components.

Niches form the micro-level, the locus where novelties emerge. These can be small market niches or technological niches, where resources are provided by public subsidies (Kemp et al., 1998, 2001; Raven, 2005). Niches act as 'incubation rooms', shielding new technologies from mainstream market selection. Such protection is needed because new technologies initially have low price/performance ratio. Protection comes from small networks of actors who are willing to invest in the development of new technologies. Important niche-internal processes are: building of social networks, learning processes and articulation of expectations to guide learning processes. The macro-level is the socio-technical landscape, which forms an exogenous environment that usually changes slowly and influences niches and regime dynamics.

The relationship between the three levels is a nested hierarchy (Fig. 2). Pioneers and innovators always work on novelties, but these usually remain restricted to niches (e.g. R\&D projects). New technologies have a hard time to break through, because the existing regime is stabilised and entrenched. Historical studies have shown that transitions only come about when developments at all three levels link up and reinforce each other (Geels, 2005; Van Driel and Schot, 2005).

We use this multi-level perspective to make a long-term analysis of the electricity domain. Section 2 focuses on the socio-technical regime, analysing dynamics in social networks, rules and technologies. Section 3 analyses renewable niche-innovation trajectories and regime interactions. Section 4 combines both analyses to explain the low Dutch share of renewable electricity. This section also draws conclusions about hindrances and possibilities in a future energy transition.

\section{Dynamics in the electricity regime (1960-2004)}

\subsection{Changing perceptions and goals (1960-1973)}

Before 1960 , the electricity regime was relatively stable. The dominant regime actors were regional (and municipal) 
utilities. The organising principle in the regime was regional autonomy. The utilities, and the Arnhem organisations they founded to manage the electricity system, had complete control over the system. An informal regime rule was to exclude the national government. The introduction of natural gas in the 1960s and experiences with nuclear energy led to changes in perceptions. The national government became unhappy with its position outside the electricity regime. Governmental efforts to gain more control created frictions with regime insiders.

The government took a leading role in the introduction of natural gas. A public-private cooperation was set up between the Dutch state, Shell and Exxon, and a new actor (Gasunie) was created with a national monopoly on natural gas exploitation. The introduction strategy focused on the market for space heating in households and buildings. This market niche allowed high prices and profits, with the Dutch State as main recipient. Because of this strategy, the electricity sector was initially excluded from buying gas. Hence, natural gas was used on a limited scale in the electricity sector until 1968. Thereafter gas-fired plants were introduced and the share of natural gas in the electricity sector increased to about $80 \%$ in the mid-1970s, rapidly replacing coal (and oil) (Correljé et al., 2003). Natural gas functioned as exemplar for the national government, changing ideas about its role in energy systems.

The new gas system also enabled the introduction of gas turbines. Although gas turbines had a lower fuel efficiency and smaller capacity than the dominant big steam turbine plants, their advantage was a short start-up time. Other advantages were the short time to build a new gas turbine unit and low upfront investments. In the mid-1960s, electric utilities adopted gas turbines for peak-load generation, in response to power blackouts that occurred when demand exceeded supply (Hesselmans et al., 2000).

The Dutch government was also actively involved in the introduction of nuclear energy, aiming ambitiously to establish a Dutch nuclear industry. This path started outside the electricity regime through promises from scientists about the potential of nuclear energy in the late 1940s. Several large projects were started and financially supported by the government. Regime insiders also became interested. But it proved difficult to align the different actors. To government's frustration, the utilities went their own way, starting their own research programme in the mid-1950s (Lagaaij and Verbong, 1999). Relationships between utilities and the government further soured in 1969, when one of the utilities purchased the Borssele nuclear plant in Germany. This action undermined the government's policy to establish a domestic nuclear industry.

These developments affected the social netwok in the electricity regime (Fig. 3). The government wanted to reduce its outsider position and increase its influence. The government also stimulated large industry. Industry and households were important, because their growing demand

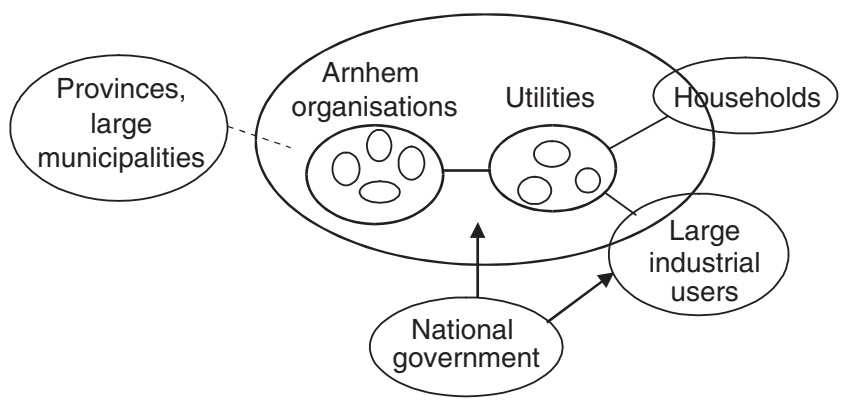

Fig. 3. Actors and networks in electricity regime (1960s).

provided space for continued expansion of the electricity regime. From the beginning of the 20th century, increasing demand was met by increasing the scale of power units and voltages. But households and industry had little influence on design choices, and remained relative outsiders.

Gas and nuclear power point to an implicit new guiding principle, namely that energy policy became part of industrial policy, both of which resided under the Ministry of Economic Affairs (Lagaaij and Verbong 1999).

\subsection{Direct government interventions (1973-1989)}

The oil crisis of 1973 formed an external landscape shock, to which the government reacted with its first Energy White Paper (1974). This document addressed environmental and scarcity issues, and formally increased the government's influence in the electricity regime by transferring the final say on fuel use in power stations and the purchase of nuclear plants to the minister of Economic Affairs. Furthermore, the document introduced integral thinking in energy policy. Two guiding principles remained important: provide cheap energy for large industries, reliability of supply. With the White Paper two new criteria were added: diversification of energy resources to reduce dependency, and energy efficiency to reduce environmental impacts.

Regime actors were unhappy with the government's increased role in the regime and restrictions on their autonomy. The utilities perceived environmental problems as perfectly solvable within the existing system, e.g. by increasing overall efficiency and add-on technology to clean waste gases. For them, the main problem was stagnation of electricity demand in the 1970s, which disturbed long term planning.

The 1970s and 1980s saw major changes in the fuel mix. After 1968 natural gas rapidly became the main fuel. Until the oil crisis, the guiding principle was to consume the gas rapidly, because large-scale introduction of nuclear energy was expected to reduce the commercial value of gas. The oil crisis changed this perception. The government came to see gas as valuable commodity and strategic resource that was not to be used cheaply in power stations. To the frustration of the electricity sector, the government restricted the use of natural gas, and enforced increased use of oil, despite 


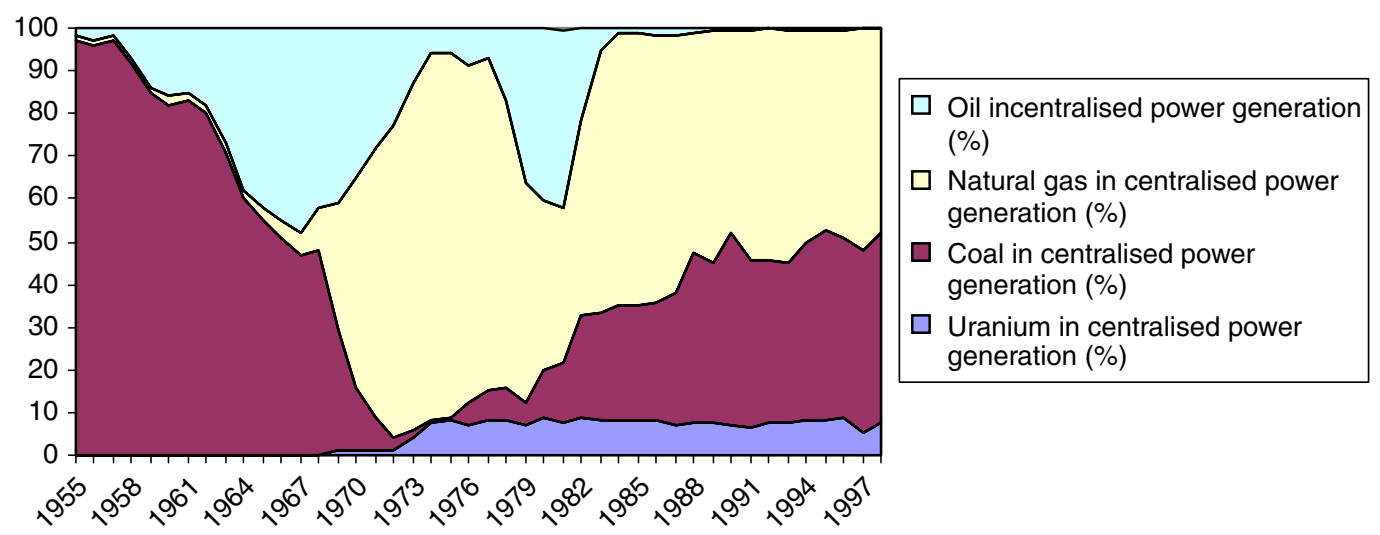

Fig. 4. Fuel mix in Dutch utility electricity production (data from Rob Raven on the basis of several SEP reports).

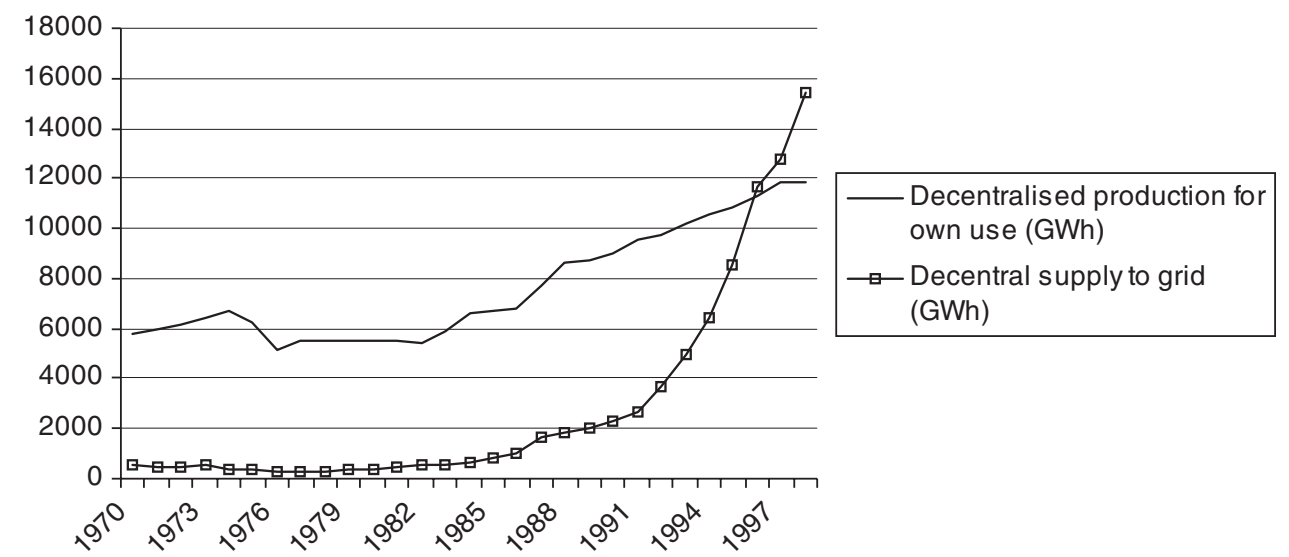

Fig. 5. Grid supply and own use of decentralised electricity (based on data from Rob Raven on the basis of several SEP reports).

high prices (Fig. 4). This strategy deviated from other European nations which tried to reduce oil dependency.

Another development occurred in electricity production by large industries. In 1968 large industries generated $3200 \mathrm{GWh}$, equivalent to $10.6 \%$ of total Dutch electricity consumption (Blok, 1993). Almost all of this power was used for private purposes and not delivered to the national grid (Raven and Verbong, 2006). Only in the late 1980s the delivery of decentral electricity to the grid accelerated (Fig. 5).

Many of the self-generating industries also produced heat in combined heat and power plants (CHP). The relative share of industrial $\mathrm{CHP}$ in decentral power increased to $95 \%$ in 1988 . Underlying this rapid increase was a shift from steam turbines to gas turbines. Between 1968 and 1988 about 85 new industrial CHP units were installed. Of the total installed capacity, $1000 \mathrm{MW}$ consisted of gas turbines and $200 \mathrm{MW}$ of steam turbines (Blok, 1993). The gas turbine also benefited from a new design concept: the Combined Cycle Gas turbine (Watson, 2004). Developed in the late 1970s and early 1980s, this concept implied a reversal of roles, with gas turbines becoming the dominant production system and steam turbines becoming auxiliary devices.
In the 1970s, the growth of decentral electricity production occurred without explicit government support. But large industrial users, the chemical industry and aluminium producing companies, lured to the Netherlands with cheap gas, increasingly organised themselves to improve their negotiation position with the utilities (Hesselmans et al., 2000). Goals and perceptions further changed with the second oil crisis in 1979, a big landscape shock leading to much higher energy prices. The government published a second Energy White Paper (1979), introducing extra goals and measures. Energy saving became top priority. Already in 1978 the advisory council for energy policy emphasised the energy saving potential of industrial CHP. But there were two obstacles: (a) low feedback tariffs and opposition from the electricity sector to include industrial CHP in their planning, (b) the national gas policy, which limited the amount of gas available for steam generation in industry. To solve the first problem, the government started negotiations with industry and the electricity sector. The government felt that talks proceeded slowly and forced the electricity sector to connect industrial CHP plants to the grid without extra charges. Also tariffs for electricity feedback to the grid were established (Raven and Verbong, 2006). The second barrier was removed in 1983 when the 
government changed the gas policy to provide big industries with cheap natural gas for cogeneration. So again energy policy was part of industry policy. With the obstacles removed and with positive investment incentives, decentral electricity gathered speed after 1983 (Fig. 5). Industrial CHP accounted for much of this growth (Blok, 1993). In 1985 energy prices fell significantly, but this did not slow CHP diffusion.

With regard to the fuel mix of utilities, the policy on increased oil use was stopped after the second oil crisis and coal was rapidly reintroduced (Fig. 4). But extra measures were needed to reduce environmental impacts. In the early 1980s there were high expectations about coal gasification, but it soon became clear that commercial viability would take more than five years. Hence, emphasis shifted to flue gas cleaning technology and new types of fluidised bed reactors.

The government also favoured more nuclear power, but was wary of societal opposition. Between 1981 and 1984 a societal debate was organised on energy policy, but no consensus was reached. The Tsjernobyl accident (1986) ended the debate. The accident also revived interest in coal gasification, leading to an innovative project at Buggenum. Although investments were over $400 \mathrm{M} €$, the project failed commercially, mainly because liberalisation in the late 1980s changed selection criteria and strategies (Harmsen 2000).

Fig. 6 summarises main dynamics in social networks in this period. The national government became part of the regime with increased formal powers and responsibilities. CHP transformed large industries into decentralised electricity producers, making them also part of the regime. Decentralised CHP created pressure on utilities, because this capacity was not under centralised control. Furthermore, they could no longer dictate conditions for grid connection.

Another important landscape development of the 1980s was the economic recession. Efficiency, cutbacks and privatisation were guiding principles of the first centreright Lubbers Cabinet (1982-1986), which also affected the electricity regime. The government perceived the large number of production and distribution companies as barrier for efficiency. There was talk about merging all utilities in one national company. To prevent this, the electricity sector pro-actively introduced a national planning system in 1982. In this system, the most efficient

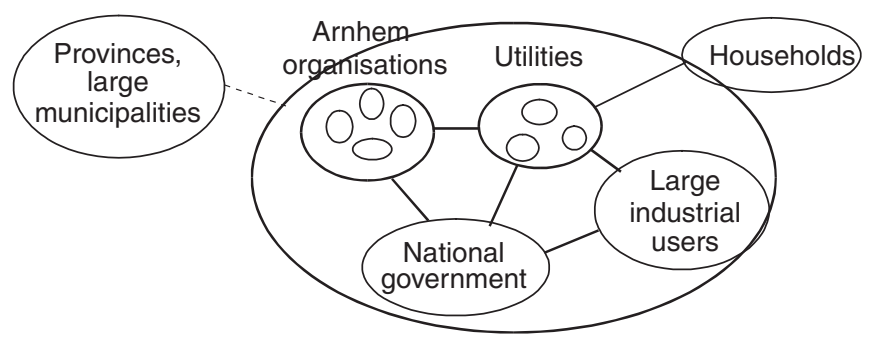

Fig. 6. Actors and networks in electricity regime (1970-1980s). power plant was connected to the national grid first. This was a major change, because previously every regional utility was responsible for balancing supply and demand in its own region. Under the new arrangement, Dutch utilities also started to import electricity from abroad, particularly during the night when German and French nuclear power stations offered cheap power (Verbong, 2006). But the government was not impressed with the new arrangement and pushed for further restructuring. Again, the utilities acted pro-actively, concentrating production in four regional companies. Also the number of distribution companies was reduced. But the measures were too little, too late. In 1989 a new law was implemented.

\subsection{Major changes in rules, networks and technology (1989-2004)}

The 1989 Electricity Law implied major changes in formal rules and social networks, initiating a transition in the electricity regime. Aiming to enhance dynamism and efficiency, the Law enforced separation of electricity production and distribution and created a new actor: the energy distribution company (EDC). The Law also introduced market mechanisms on the supply side. Electricity production by other actors (industrial firms, EDCs) became free and a national standard base tariff was established for grid supply. After several mergers, four large EDCs dominated the market (Nuon, Essent, Eneco, Delta). They bought electricity from competing production companies. Production companies were accustomed to cooperation and collective long-term planning. The new Electricity Law replaced this internal planning mechanism with the market mechanism, signalling a major change in governance structures.

The new Electricity Law also allowed EDCs to generate electricity on a small scale. But EDCs circumvented this limitation by setting up joint ventures with industrial companies for the construction of large-scale CHP plants. For EDCs this was a strategic move, aimed at becoming a player in electricity production. For decentral electricity producers this new alliance was beneficial, because it gave them better grid access and possibilities to sell excess electricity (Verbong et al., 2001).

In this new context, decentralised generation expanded rapidly in the 1990s (Fig. 5). Most decentral production came from industrial CHP, but also increasingly from district heating and horticulture (Fig. 7). This expansion was accompanied by a technical design change resulting in bigger CHP plants. Previously, the design of CHP plants was based on local electricity demand. Additional electricity production did not pay, because of low refunds for grid supply. With the new rules and tariffs, CHP plants could be designed on the basis of local heat demand (which was bigger than electricity demand). Excess local power was supplied to the grid (Raven and Verbong, 2006).

Environmental problems and climate change were external landscape developments that also stimulated 


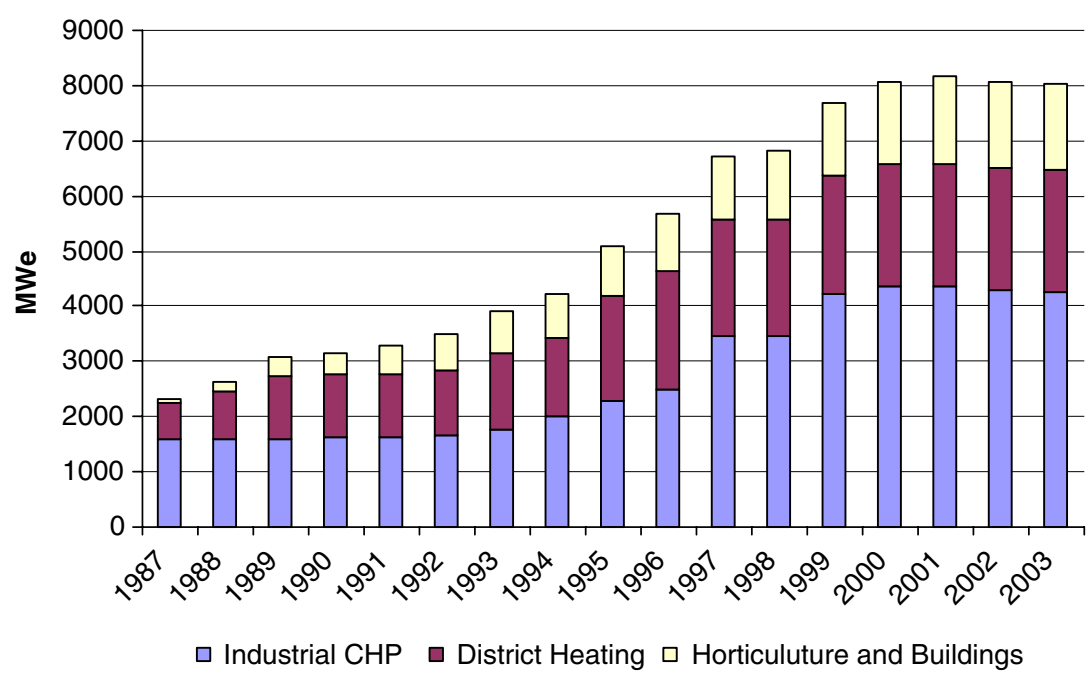

Fig. 7. Total Installed electric capacity of CHP in the Netherlands (Raven and Verbong, 2006).

CHP diffusion. CHP was seen as an important way to reduce $\mathrm{CO}_{2}$ emissions. Hence, the Ministry of Economic Affairs stimulated CHP by creating a project bureau to encourage and carry out CHP feasibility studies for users such as hospitals, horticulture and other industrial sectors. The Ministry also implemented new investment grants for CHP, and a limited decrease in the natural gas price for CHP users. These measures made CHP investments profitable. Commitments to improve environmental performance were another reason for large industries, horticulture and EDCs to become more interested in CHP (Raven and Verbong, 2006).

The rapid expansion of CHP led to a crisis in planning and monitoring procedures in the electricity system. An increasing part of electricity production occurred outside the centralised system, but feedback to the grid had to be accepted. This created problems in matching supply and demand. Moreover, production companies underestimated decentralised production and started preparations for new power plants. The extra decentral capacity resulted in overcapacity. In 1994, all CHP subsidies were abandoned and production and distribution companies agreed on a half-year moratorium on new CHP plants. But when the moratorium ended, decentral CHP growth continued.

These capacity problems were partly due to a stubborn attitude of central production companies. But there was also confusion about ownership structure. Although production and distribution were supposed to be separated, EDCs had the shares of production companies (and the provinces those of EDCs). Within a few years, three of the four centralised production companies were sold to international companies. Privatisation and planning failures had eroded the grip of the once all-powerful utilities.

By 2000 CHP had become the dominant form of electricity generation. CHP expansion came to a halt because of rising natural gas prices, decreasing electricity prices, and competition from large international suppliers (Van Oostvoorn, 2003). Also the efficiency advantage of cogeneration diminished, because technological development in CCGT units led to higher electrical efficiencies (up to $60 \%$ ).

Adjustments in the regulatory framework were needed, because of capacity problems, confusion over ownership structures, and because of accelerated European integration following the Maastricht Treaty (1992). Liberalisation, privatisation and deregulation became key words nationally and on a European scale. EU member states agreed to liberalise energy markets, with the Netherlands as one of the frontrunners. In 1998 a new Electricity Law was adopted, which extended the market mechanism to consumers. Big users were the first to choose their own supplier, followed by households in 2004. The Law created a new organisation for the operation and maintenance of the high voltage grid (Transmission System Operator). EDCs had to transfer their network distribution activities to a new, formally independent part of their organisation. The remaining parts of the EDCs completed their transformation into commercial companies, buying electricity from suppliers (or generating it themselves) and selling it to consumers. The government withdrew from the electricity regime, delegating responsibilities and supervision to a newly established regulator. The Law implied the official disintegration of the traditional network. Fig. 8 summarises the new social network in the late 1990s. The next planned step was the privatisation of EDCs. But external landscape factors (energy blackouts in California, terrorist attacks, dependency on politically unstable regions) placed reliability and vulnerability of critical infrastructures high on the political agenda. Hence privatisation of EDCs was delayed. Instead, policy makers pushed for formal separation of the distribution part from EDCs, a contested and not yet completed move. ${ }^{1}$

\footnotetext{
${ }^{1}$ NRC-Handelsblad, Dossier, elektriciteit, e.g., Kabinet: stroom-en gasnet deels verkopen, 29 August 2005, http://www.nrc.nl/dossiers/ Elektriciteit.
} 


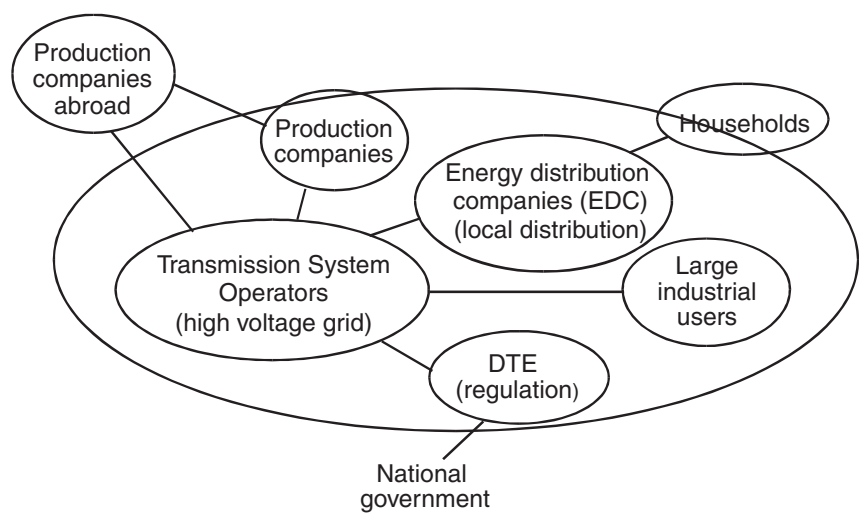

Fig. 8. Actors and networks in electricity regime (late 1990s).

Another development in the 1990s was increasing electricity imports by EDCs (Fig. 9). The expanding international electricity trade increasingly links national grids together. The emergence of a European electricity system is a complicated process that encounters many technical problems. In particular, the introduction of largescale fluctuating production capacity, for example large offshore wind parks, provides severe problems for balancing demand and supply. This has already led to some international blackouts. There are several technological solutions, but they all require large investments and make the whole system more complicated (Kema, 2004). Another problem is increasing congestion on interconnectors between countries. In the Trans European Networkprogram, the EU has selected several projects for the reinforcement of specific international connections. ${ }^{2}$ The ongoing Europeanisation of electricity systems will require much attention for technical, financial and regulatory problems.

\subsection{Conclusions}

We draw the following conclusions about dynamics in the electricity regime. First, a transition has been unfolding in the last decade. Major changes have occurred in rules and social networks of the electricity regime. Production and distribution have been separated, internal planning mechanisms have been replaced by market mechanisms, companies are privatised, new actors with new roles were created. Guiding principles have also changed. High grid reliability, part of the engineering mind frame, has been replaced by profits, shareholder value and a managerial mind frame. There were also technical changes, especially the rise of gas turbines and CHP, which enabled the rapid expansion of decentralised production. The increasing share of distributed generation (and renewable energy sources) increased the need for monitoring and measuring, and required technical adjustments in the grid. In sum, a regime shift is unfolding related to liberalisation and

\footnotetext{
${ }^{2}$ See http://europa.eu.int/comm/ten/energy/index_en.htm.
}

privatisation. The European dimension is an extra dimension of this ongoing transition with the Dutch electricity system becoming part of an emerging European electricity system. The transition is ongoing. Technical, institutional and financial aspects will require much attention in the next decade(s).

Second, the ongoing transition is not caused by one single event or driver. There is no rapid shift from one equilibrium to another. Instead, the transformation process proceeded with bigger and smaller steps, dating back to the 1960s. Several changes linked up and resulted in the major change of formal rules in 1989. There were socio-technical 'leap frog dynamics' in the sense that formal rule changes led to changes in social networks, which led to changes to technology, which led to unintended overproduction and breakdown in planning mechanisms, which led to new formal rule changes, etc. Dynamics were stepwise and coevolutionary, with rules, actors and technologies influencing each other. Another conclusion with regard to the type of dynamics is that regime transformation was strongly influenced by external landscape developments. The reason for this sensitivity to external developments is probably the importance of electricity for western societies in general.

A conclusion with regard to government policy is that many shifts and changes occurred, sometimes reversing previous policies. Coal was phased out and replaced by gas in the 1960s and early 1970s. But gas use was restricted after the first oil crisis, while oil use was stimulated. After the second oil crisis, coal was reintroduced, oil use was diminished, and gas policies became more abundant. Government interventions also had unanticipated consequences, e.g. the electricity law of 1989 that led to unforeseen problems (in ownership structures, overcapacity).

Although much has changed, some implicit rules remained stable. Energy policy has remained part of wider industrial policy. Also guiding principles have remained relatively constant, organised hierarchically as follows: (a) cheap, low cost (as part of industrial policy), (b) reliability, (c) diversification, (d) environmental issues. This links up with the first conclusion that the main drivers in the ongoing energy transition are liberalisation/privatisation and Europeanisation. Climate change and environmental sustainability have been added as additional considerations, but are not main drivers.

This last conclusion begs the question if the electricity system is heading in a more sustainable direction. To address that issue, we will analyse several renewable nicheinnovation trajectories.

\section{Renewable electricity and niche-innovation trajectories}

Renewable energy is relatively small in the Netherlands (Fig. 1). One explanation is that renewable energy has not been a top priority in Dutch energy policy. The Third Energy White Paper (1995) formulated high ambitions: $10 \%$ renewable energy in 2020 . But there is a gap between 


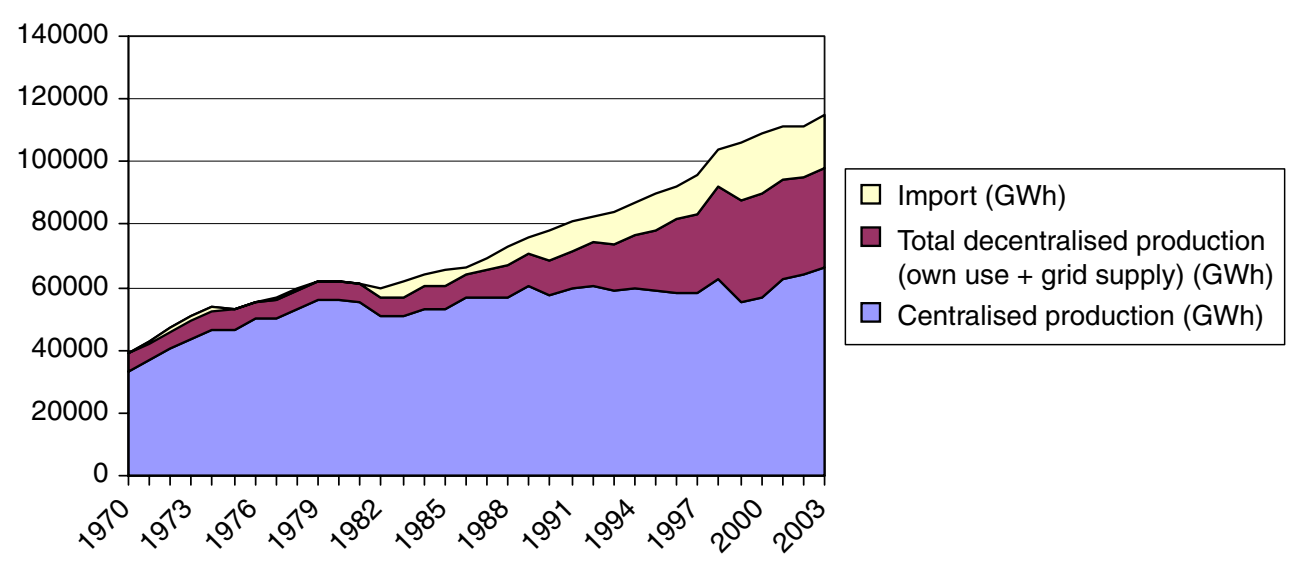

Fig. 9. Dutch imports, centralised and decentralised production (based on data from Rob Raven and CBS).

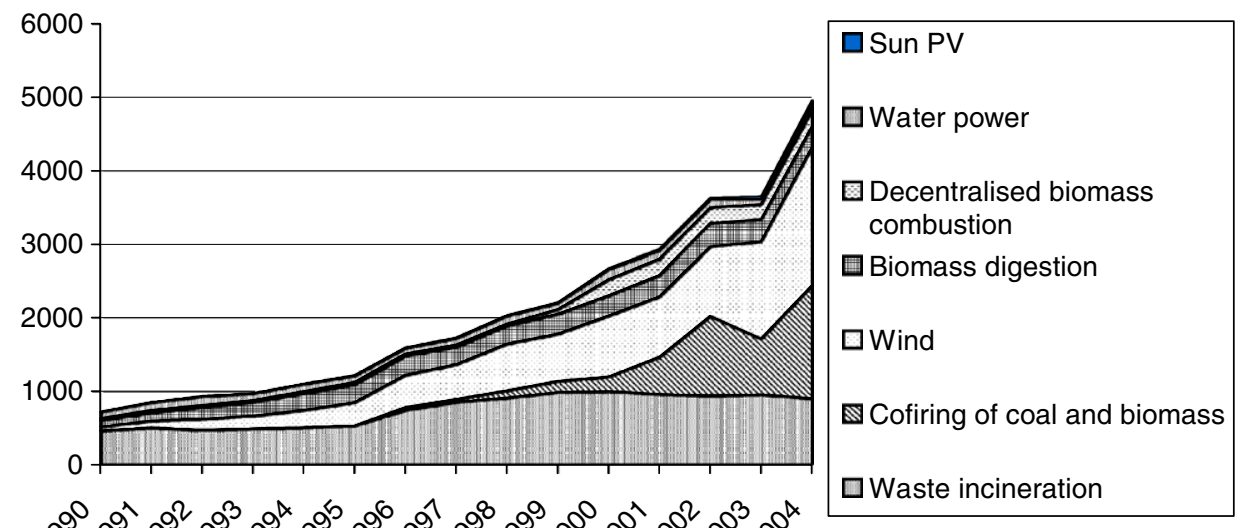

Fig. 10. Dutch renewable electricity production (GWh per year) (data from CBS).

policy goals and real policy measures. Liberalisation and Europeanisation have received more policy attention than renewable energy. A second explanation is that energy saving received more attention than renewable energy. This has led to big improvements in energy efficiency in Dutch industry (Kempener, 2003).

With regard to renewable electricity, there are signs of hope, but also reasons for moderate pessimism. A sign of hope is that total renewable electricity has grown substantially, from less than $1 \%$ of total electricity consumption in 1990 to $3.8 \%$ in 2004 (Fig. 10). Initially, renewable electricity came primarily from burning waste. Gradually wind became more important, supplemented in the last five years by rapid growth of co-firing of biomass and coal.

There were two important drivers for the growth of renewable electricity. One driver was the stimulation of market demand, following the introduction of an energy tax in 1996. Because renewable energy sources were exempted, the price gap between 'normal' and 'green' electricity was lowered, stimulating demand. The fiscal support for 'green electricity' gradually increased to $0.06 € \mathrm{kWh}$ in 2002 , supplemented by $0.02 € / \mathrm{kWh}$ for production support (Van Rooijen and Van Wees, 2006). In effect, green electricity was about the same price as normal 'grey' electricity. The second driver was activism from EDCs. Although EDCs put most of their efforts in CHP, they also stimulated 'green electricity' through advertising campaigns to boost their green image.

The number of green electricity consumers rapidly increased from 16.000 in 1996 to 1.4 million in 2002. This rapid increase in demand could not be met with national production, and imports of renewable electricity increased. EDCs received subsidies for imported green electricity, because the tax law applied to demand, not the place of production. In 2002 , only $26 \%$ of green electricity was produced domestically (Van Rooijen and Van Wees, 2006). So the unintended effect of the energy tax was that Dutch tax money flowed to international suppliers. Hence, in 2003 the new government ended the demand-oriented energy tax exemptions, replacing it with the supply oriented MEPregulation (Environmental Quality Electricity generation). The MEP provided a fixed feed-in tariff to producers of renewable electricity plus an additional tax exemption, which was gradually phased out. The height of the feed-in tariff varied for different renewable sources, ranging from 
0.029 to $0.068 € / \mathrm{kWh}$ (Van Rooijen and Van Wees, 2006). One of the lessons from previous subsidy schemes was that they should be guaranteed for a longer time period. Hence, the MEP scheme was initially set for 10 years. But within two years the minister of Economic Affairs downscaled subsidies, because increasing proposals for wind parks implied an enormous budget increase.

The green electricity market has recently stagnated. Rising energy prices could even result in a switch back to the cheapest provider. On the other hand, current highenergy prices improve the competitive position of renewable energy options. The contribution of different renewable sources is still relatively small, and often restricted to particular niches. The following sub-sections focus on the long-term dynamics of three niche-innovation trajectories, analysing social networks, expectations and learning processes, as well as relationships to regime actors.

\subsection{Wind energy}

Following the first energy crisis, interest in wind energy increased. From the start of a national energy research program in 1976, incumbent regime actors played an ambiguous role in the social network supporting wind energy (Verbong, 1999). In the early phase, they were sceptical but sympathetic. From the perspective of the electricity system, wind energy could only contribute significantly by constructing large wind parks with high capacity turbines. This search heuristic for big, breakthrough designs proved difficult: most large turbines broke down or did not function at all. In contrast, the Danes conquered the market with a bottom-up approach, starting with small-size turbines, followed by gradual upscaling (Jørgensen and Karnøe, 1995; Van Est, 1999). The innovative two-bladed design, favoured by the Dutch (and Americans and Germans) lost out to the more conservative three-bladed Danish design (Kamp et al., 2004).

The large-scale focus was contested by the grass roots movement. But the development of small-scale, autonomous turbines also failed, reinforcing the expectation that only grid-connected turbines had a future (Verbong et al., 2001). Hence, the relationship with the existing electricity regime was seen as crucial for further development of wind energy. But several tensions occurred in the social network.

The first conflict occurred in the early 1980s when the construction of a wind park was planned. Regime actors argued that this park should be seen as a power plant, and that they should have control. They succeeded in wrestling the park out of the national research framework, leading to tensions in the social network. Relationships between the electricity regime and turbine industry further deteriorated, when the project failed because of unreliability of the wind turbines. One industrial company quit, complaining about the utilities' arrogance. The company that supplied the turbines almost went bankrupt (Verbong, 1999).
Another issue was the impact of wind energy on the electricity system. Because of fluctuations and unpredictability of wind energy, the electricity sector estimated that only $650 \mathrm{MW}$ of wind turbine capacity could be connected without endangering the system. This was contested by the Dutch Energy Research Centre, an important participant in the wind energy network, who came with higher estimates (2500 MW) (Verbong et al., 2001). The key issue was (and is) that wind turbines always need spare capacity to provide backup during windless periods, and therefore cannot replace existing production units. Normally, utilities paid electricity suppliers for the amount of current supplied, topped up with a capacity fee (based on saved capacity). But for wind energy, the electricity sector did not want to pay such a capacity fee. This formed a barrier for local initiatives by co-operatives and private wind associations. The costs for connecting wind turbines to the grid were another barrier (Verbong et al., 2001). Both barriers were not removed until the late 1990s. By then the involvement of newly formed EDCs led to new dynamics in the social network and new support for wind energy.

Despite disappointments in the 1980s, the Dutch position was still good in 1990, compared internationally (Bergek and Jacobsson, 2003). But ten years later, ambitions were shattered. The goal for the year 2000 $(1000 \mathrm{MW})$ was not met by a large margin. It proved difficult to find locations for wind turbines. Local residents increasingly protested against siting plans. Dutch industry was swept away by Danish firms and future perspectives for wind energy were bleak (Verbong et al., 2001). Offshore wind parks seemed to be the solution, but permit procedures, negotiations with nature conservationists and uncertainty over financial support schemes delayed these projects.

During the last five years the symbolic image of wind energy weakened considerably. Environmental groups came to see wind turbines as disturbances of the natural landscape, 'bird shredders', and noisy, ugly objects. Electricity production companies see wind turbines as unreliable and a danger to stability of the electricity system. Politicians increasingly perceive wind turbines as a not very cost-effective way of reducing greenhouse gases. An underlying cause of these problems is the neglect of societal embedding of wind energy, with innovation activities focusing only on technical aspects. It seems difficult for wind energy to break out of this situation. Offshore potential is considerable, but chances of overcoming barriers in the short term are slim.

\subsection{Biomass}

Adding biomass to coal-fired plants (co-firing) has become the largest biomass application in the last decade (Raven, 2005). There have been major shifts in visions on biomass. A mundane, but important issue is the definition of biomass. In the early 1980s the government made a 
distinction between waste (sludge, organic waste) and biomass (wood, cultivated energy crops). This distinction became increasingly blurred in official reports, as energy from waste grew rapidly. In the 1990s, the debate on biomass definition heated up. Environmental groups felt that waste, which was not sustainable, should be distinguished from sustainable biomass. Despite their protests, the biomass definition was broadened to include all organic streams that can be used for energy production. Because energy from biomass was considered renewable, it was exempted from the energy tax in the late 1990s. This rule also applied (partly) to energy production from organic waste in waste combustion installations (Verbong et al., 2001). The tax exemption made biomass financially attractive and stimulated interest from EDCs, production companies and other energy suppliers, expanding the social biomass network.

Contrary to wind energy, the production of electricity from co-firing biomass was linked closely to the electricity regime from the start. In the mid 1990s electricity production companies introduced co-firing on a smallscale, because changes in the waste regime made this commercially attractive. Utilities could earn 'gate fees' that would otherwise be paid for the dumping of waste streams. Exemption from the 1996 energy tax offered commercial opportunities for green electricity production. But a more vigorous greenhouse gas reduction policy threatened the operation of coal-fired plants. Production companies had to choose between switching to costly natural gas and increasing the level of biomass to reduce $\mathrm{CO}_{2}$ emissions. They chose the latter and increased amounts of biomass in coal plants. Experience changed perceptions as it was learned that more biomass could be co-fired than initially expected. But uncertainty still exists about the influence of increased biomass inputs on the life span of plants (Raven, 2005).

Similar to wind energy, environmental groups and local residents opposed wide diffusion of co-firing. They were concerned about higher emissions of mercury and other heavy metals when waste or painted wood were used. Most co-firing plants encountered problems in permit procedures. Environmentalists argued that stricter rules from the waste regime should be applied if plants used waste. Production companies responded that waste should be considered as biomass, which implied that certain emissions in co-firing plants were allowed to be somewhat higher. But these arguments and legal procedures caused delays and uncertainties, because courts sometimes ordained that new applications had to be written.

Co-firing of biomass has rapidly diffused, improving environmental performance of the electricity sector. The practice of co-firing is close to the incumbent regime, building on existing competences with coal combustion. Experiences with more radical co-firing options, such biomass gasification before combustion, have been disappointing. In the mid-1990s, there were optimistic ideas about this option, building on knowledge from previous coal gasification projects. But a concrete biomass gasification project at the Amer power plant has been plagued by technological problems (Raven, 2005).

\subsection{Photovoltaic (solar PV)}

Photovoltaics cells were first used in space. After the first energy crisis, research also focused on other applications such as remote locations without grid connection, e.g. streetlamps, harbour beacons. Rural areas in developing countries formed an early niche market for stand-alone solar home systems. But in the 1970s PV was not (yet) part of sustainable energy visions. Policy makers and experts considered PV unfeasible, because of the Dutch geographical position and climate. Nevertheless, PV-research occurred at several universities. Researchers formed a PV lobby to persuade policy makers, industrial companies, utilities and environmental organisations to support research and demonstration projects. These projects demonstrated that PV could be applied in the Netherlands. Projects abroad also contributed to an increasing appreciation of PV in the early 1980s. By the late 1980s, ideas about grid-connected PV systems appeared, but high costs were an important stumbling block.

Within a few years, perceptions changed completely. In the early 1990s, PV came to be seen as the ultimate renewable energy option for the (long-term) future. There was a broad societal support for PV and budgets for research and demonstration projects increased significantly. The environmental movement embraced PV, because it had grown increasingly sceptical about other renewable options. Also Shell embraced PV in its scenarios, portraying it as major energy source by the mid-21st century. This vision influenced NGO's and policy makers. In the Third Energy White Paper (1995) PV featured as main long-term renewable option, together with biomass. Greenpeace and Nuon began ambitious projects to encourage the diffusion of PV panels among Dutch households (Verbong et al., 2001).

Although expectations were high in the mid-1990s, electricity from PV was much more expensive than other renewable options and grey electricity. Hence, technical development focused on higher conversion efficiency of solar cells and reduced productions costs (Perlin, 2002). Despite technological progress, the $\mathrm{kWh}$ price remained very high. In the late 1990s the government re-evaluated renewable options using two criteria: (a) contribution to greenhouse gas reduction, (b) cost-efficiency. PV scored poorly on both criteria: total contribution to renewable electricity was negligible and costs were very high. As a result, policy attention shifted back to wind and biomass. PV implementation has recently stagnated, although societal support is still high. For electricity regime actors, $\mathrm{PV}$ is a minor niche. The impact on the system is small and regime actors are hardly involved in PV projects (with a few exceptions to boost green image). 


\subsection{Conclusions about niche-innovation projects}

With regard to the dynamics of renewable nicheinnovations, we conclude that trajectories have long histories and are non-linear with many ups and downs. Over the years, there have been several widely shared visions that triggered enthusiasm for some time, but eventually failed, e.g. wind in the late-1970s, PV in the mid-1990s. Initial expectations were frequently too high, technical problems were bigger than expected, and implementation was slower than anticipated. We also conclude that niche-dynamics were highly influenced by developments at the landscape and regime level, e.g. oil prices, environmental concerns, economic recession, climate change, liberalisation, creation of EDCs. A recurring pattern is that disappointments in one niche-innovation are followed by increasing expectations in another. Policy makers and consultants support a niche-innovation when expectations are high. But when learning processes and outcomes are disappointing, the bandwagon moves on to another niche-innovation. The underlying explanation is the need for these actors to appear visionary in response to societal demands for sustainability.

A second conclusion is that the long-term analysis indicates several reasons for failure of niche-innovation trajectories. One reason is that many trajectories had a technology-push character (driven by R\&D). The underlying explanation is that several innovations were not only sponsored for sustainability reasons, but also to set up Dutch industries. Energy policy is often a branch of industry policy. A second reason is little attention for the societal embedding of new technologies. The technologypush approach led to protests from societal groups, which were able to slow down implementation. It might have been better to involve these actors earlier in the innovation process. A third reason is that government policy has not provided long-term guarantees and stability (Van Rooijen and Van Wees, 2006). Policymakers too rapidly abandon innovations when learning processes are more difficult than expected. Shifts in policy, almost every few years, create uncertainties and hamper investments.

\section{Conclusions}

Policy makers, NGO's and academics have recently shown much interest in energy transitions, because of the promise of large jumps in environmental efficiency. It is often rhetorically argued that major system changes are the only way to achieve large jumps in environmental efficiency. The multi-level perspective on transitions suggests that radical niche-innovations are seeds for such system changes. Indeed, debates about transition management and system innovation give much attention to potential and barriers for renewable energy options, and possible policy measures to stimulate them. Although such measures and analyses are important, they are often limited, because they are not situated in a broader regime analysis that takes deep structural trends into account. For a balanced assessment, one should not only analyse 'pet technologies' and niche-innovations, but also broader regime developments. With regard to previous decades, Table 1 summarises how changes in social networks, technology and rules at the regime level, described in Section 2, influenced niche-dynamics for wind, biomass and solar-PV, described in Section 3.

Summary of regime influences on niche dynamics

\begin{tabular}{|c|c|c|c|}
\hline & $\begin{array}{l}\text { Social network: regime actors } \\
\text { involvement }\end{array}$ & Technology: fit with existing system & Regime rules \\
\hline \multicolumn{4}{|l|}{ Wind } \\
\hline 1970s & Wait-and-see attitude utilities & & No issue \\
\hline 1980s & Tensions in social network & $\begin{array}{l}\text { Mis-match; problem load } \\
\text { management, grid connection }\end{array}$ & $\begin{array}{l}\text { Struggles over capacity fee, and grid } \\
\text { connection }\end{array}$ \\
\hline $1990 \mathrm{~s}$ & $\begin{array}{l}\text { Regime network falls apart; active } \\
\text { EDCs, reactive production companies }\end{array}$ & $\begin{array}{l}\text { Idem, but now also on European } \\
\text { scale; more complex system }\end{array}$ & Laws compel grid connection \\
\hline $2000 \mathrm{~s}$ & $\begin{array}{l}\text { Idem; environmentalists withdraw } \\
\text { support }\end{array}$ & Idem & $\begin{array}{l}\text { Financial and regulatory problems at EU } \\
\text { level }\end{array}$ \\
\hline \multicolumn{4}{|c|}{ Biomass } \\
\hline $1990 \mathrm{~s}$ & $\begin{array}{l}\text { Active production companies because } \\
\text { of economic considerations }\end{array}$ & Close to dominant practice, add-on & Gate fees from waste regime, energy tax \\
\hline $2000 \mathrm{~s}$ & $\begin{array}{l}\text { Idem, but also climate change pressure } \\
\text { on coal-fired plants }\end{array}$ & $\begin{array}{l}\text { Increase biomass percentage in } \\
\text { cofiring }\end{array}$ & CO2-emission reductions (covenant, 1999) \\
\hline \multicolumn{4}{|c|}{ Solar-PV } \\
\hline 1980s & No interest & Grid connection no issue & Vision limited niche market \\
\hline $1990 \mathrm{~s}$ & $\begin{array}{l}\text { Seen as long-term option, EDCs } \\
\text { active (green profiling), support from } \\
\text { Shell, Greenpeace, government }\end{array}$ & Grid connection no issue & Shift to high expectations \\
\hline 2000s & Decreasing interest & Grid connection no issue & Disappointment and lower expectations \\
\hline
\end{tabular}


With regard to the future we are somewhat pessimistic about the potential of radical niche-innovations to bring about a major system change in the direction of sustainability in the electricity sector. We do not expect such a transition to take off in the next 10 years. The electricity regime is currently in flux with much uncertainty about the future. At present, the ongoing energy transition is driven more by liberalisation and Europeanisation than by environmental concerns. Environmental problems are receiving more attention in the regime, but in terms of guiding principles, they rank below the issues of low cost (as part of industrial policy), reliability, and diversification. Furthermore, most renewable niche-innovations have run into troubles in implementation and societal embedding. Wind turbines have acquired negative symbolic meaning and resistance from local communities. High expectations of solar-PV have been scaled down, because of high costs and small contributions. Biomass, in particular co-firing of biomass and coal, is more or less the only feasible renewable option at the moment. In technical and functional aspects, this innovation is close to the existing regime, and does not require too many adaptations in existing practices. The option builds on existing competences with coal burning, and is supported by incumbent actors. Utilities had the competence, resources and motives to make this option a success. Although co-firing has substantial environmental benefits, it does not (yet) constitute a radical system change. But maybe it can act as stepping-stone for further changes in the future. Given the disappointments around many renewable sources, attention has also shifted back to coal, particularly in combination with $\mathrm{CO}_{2}$ sequestration. Although this is an add-on technology to existing practice and not a major system change, it may offer environmental benefits. So for reducing $\mathrm{CO}_{2}$ emissions, we expect that the most promising route for the next 10 years is adjustment of the existing regime through energy efficiency, more efficient gas turbines and CHP, co-firing of biomass and coal (with possibilities of spillovers to other biomass applications), and clean coal technology and $\mathrm{CO}_{2}$ sequestration. Environmental benefits of these adjustments in existing systems can be substantial. This means that we do not agree with all the rhetoric that major sustainability gains can only be achieved through major shifts to new systems.

This does not mean, however, that transition policy should only support incremental adjustment options. It is also important to keep the other, more radical options alive, and facilitate learning processes and network building. But it does not seem wise at this moment to choose for massive investments and stimulation programmes for more radical options. The reason is that ongoing regime developments do not (yet) provide a window of opportunity for wide uptake and diffusion of radical energy options. But if such a window emerges in the future, for instance because of climate change shocks or shifts in public opinion, then radical niche-innovations should be sufficiently developed to take advantage of it.
That is why it is important to keep them alive, and facilitate learning processes, experimentation and network building.

\section{Acknowledgements}

We want to thank Rob Raven for his useful feedback, comments and sharing of quantitative figures. We gratefully acknowledge financial support from the Dutch Knowledge Network on System Innovation and NWO.

\section{References}

Bergek, A., Jacobsson, S., 2003. The emergence of a growth industry: a comparative analysis of the German, Dutch and Swedish wind turbine industries. In: Metcalfe, S., Cantner, U. (Eds.), Change, Transformation and Development. Physica-Verlag, Heidelberg, pp. 197-228.

Blok, K., 1993. The development of industrial CHP in the Netherlands. Energy Policy 21 (3), 158-175.

Correljé, A., Van der Linde, C., Westerwoudt, T., 2003. Natural Gas in the Netherlands. From Cooperation to Competition. Oranje-Nassau Groep BV, The Hague.

Elzen, B., Geels, F.W., Green, K. (Eds.), 2004. System Innovation and the Transition to Sustainability. Theory, Evidence and Policy, Edward Elgar, Cheltenham.

Geels, F.W., 2002. Technological transitions as evolutionary reconfiguration processes: A multi-level perspective and a case-study. Research Policy 31 (8/9), 1257-1274.

Geels, F.W., 2005. Technological Transitions and System Innovations. A Co-evolutionary and Socio-Technical Analysis. Edward Elgar Cheltenham.

Harmsen R., 2000. Forces in the Development of Coal Gasification. Ph.D. Thesis, Utrecht.

Hesselmans, A.N., Verbong, G.P.J., Van den Berg, P., 2000. Elektriciteitsvoorziening, overheid en industrie 1949-1970. In: Schot, W., et al. (Eds.), Techniek in Nederland in de Twintigste Weuw, Deel II. Walburg Pers, Zutphen, pp. 221-237.

IEA (International Energy Agency), 2003. Renewable Energy Sources 2003, Paris.

Jacobsson, S., Bergek, A., 2004. Transforming the energy sector. The evolution of technological systems in renewable energy. Industrial and Corporate Change 13 (5), 815-849.

Jørgensen, U., Karnøe, P., 1995. The Danish wind-turbine story. Technical solutions to political visions? In: Rip, A., Misa, T., Schot, J. (Eds.), Managing Technology in Society. Pinter, London, pp. 57-82.

Kamp, L.M., Smits, R.E.H.M., Andriesse, C.D., 2004. Notions on learning applied to wind turbine developments in the Netherlands and Denmark. Energy Policy 32, 1625-1637.

Kema, 2004. Cross Border Capaciteit Wat en Hoe? De Nederlandse voorzieningszekerheid in Europees perspectief, Arnhem.

Kemp, R., Schot, J., Hoogma, R., 1998. Regime shifts to sustainability through processes of niche formation: the approach of strategic niche management. Technology Analysis and Strategic Management 10, 175-196.

Kemp, R., Rip, A., Schot, J., 2001. Constructing transition paths through the management of niches. In: Garud, R., Karnoe, P. (Eds.), Path Dependence and Creation. Lawrence Erlbaum Associates Publishers, Mahwah, NJ, pp. 269-299.

Kempener, R., 2003. De Energieketens van de Chemische Industrie. M.Sc Thesis, Eindhoven University of Technology.

Kooiman, J. (ed.), 1993. Modern Governance. New Government-Society Interactions. Sage, London.

Lagaaij, J.A.C., Verbong, G.P.J., 1999. Different visions of power. The introduction of nuclear power in the Netherlands 1955-1970. Centaurus 41 (1\&2), 37-63. 
Malerba, F., 2002. Sectoral systems of innovation. Research Policy 31 (2), 247-264.

Ministry of Economic Affairs, 2005. Now for Later. Energy Report 2005, The Hague.

Perlin, J., 2002. From Space to Earth. The Story of Solar Electricity. Harvard University Press, Cambridge, MA.

Raskin, P., Banuri, T., Gallopin, G., Butman, P., Hammond, A., Kates, R., Swart., R., 2002. Great Transition. The Promise and Lure of the Times Ahead. Stockholm Environment Institute and Global Scenario Group, Boston.

Raven, R.P.J.M., 2005. Strategic Niche Management for Biomass. Ph.D. Thesis, Eindhoven.

Raven R., Verbong G., 2006. Multi-regime interactions in the Dutch Energy Sector. The case of combined heat and power in the Netherlands 1970-2000. Technology Analysis \& Strategic Management, submitted for publication.

Rip, A., Kemp, R., 1998. Technological Change. In: Rayner, S., Malone, E.L. (Eds.), Human Choice and Climate Change, vol. 2. Battelle Press, Columbus, OH, pp. 327-399.

Rotmans, J., Kemp, R., Van Asselt, M., 2001. More evolution than revolution: Transition management in public policy. Foresight 3 (1), $15-31$.

Unruh, G.C., 2000. Understanding carbon lock-in. Energy Policy 28, $817-830$.

Van der Vleuten, E., Raven, R.P.J.M., 2006. Lock-in and change: distributed generation in Denmark in a long-term perspective. Energy Policy, accepted for publication.

Van Driel, H., Schot, J., 2005. Radical innovation as a multi-level process: Introducing floating grain elevators in the port of Rotterdam. Technology and Culture 46 (1), 51-76.
Van Est, R., 1999. Winds of Change. A Comparative Study of the Politics of Wind Energy Innovation in California and Denmark. Ph.D. Thesis, Amsterdam.

Van Oostvoorn, F., 2003. CHP statistics and impacts of the gas directive on the future development of CHP in Europe. Petten, Energy research Centre of the Netherlands.

Van Rooijen, S.N.M., Van Wees, M.T., 2006. Green electricity policies in the Netherlands: an analysis of policy decisions. Energy Policy 34, $60-71$.

Verbong, G.P.J., 1999. Wind power in the Netherlands 1970-1995. Centaurus 41 (1\&2), 137-160.

Verbong, G., Van Selm, A., Knoppers, R, Raven, R.P.J.M., 2001. Een Kwestie van Lange Adem. De Geschiedenis van Duurzame Energie in Nederland 1970-2000. Aeneas, Boxtel.

Verbong, G.P.J., 2006. Dutch power relations. From German occupation to The French connection. In: Kaijser, A., Van der Vleuten, E. (Eds.), Networking Europe. Infrastructures and the Shaping of Modern Europe (19th/20th centuries). Science History Publications forthcoming.

VROM, 2001. Een Wereld en een Wil. Werken aan Duurzaamheid. Fourth Environmental Policy Plan. Ministry of Housing, Spatial Planning and Environmental Affairs, The Hague.

Walker, W., 2000. Entrapment in large technology systems: Institutional commitments and power relations. Research Policy 29, 833-846.

Watson, J., 2004. Selection environments, flexibility and the success of the gas turbine. Research Policy 33, 1065-1080.

Weaver, P., Jansen, L., Van Grootveld, G., Van Spiegel, E., Vergragt, P., 2000. Sustainable Technology Development. Greenleaf Publishing, Sheffield. 